\title{
The Effect of the Adoption of Government Accounting Standards, Apparatus Competence and Accounting Information System on the Quality of Local Government Financial Reports
}

\author{
Dewi Muliyati ${ }^{1}$, Andi Mattulada Amir ${ }^{1}$, Femilia Zahra ${ }^{1, *}$, Ridwan $^{1}$, Nina Yusnita \\ Yamin $^{1}$, Muhammad Ilham Pakkawaru ${ }^{1}$, Masruddin ${ }^{1}$ \\ ${ }^{I}$ Graduate School of Accounting, Tadulako University \\ ${ }^{*}$ Corresponding author. Email: femilia.zahra@untad.ac.id
}

\begin{abstract}
The purpose of this review is to analyze the influence of government accounting procedures, apparatus and accounting information structures on the quality of local government financial statements. This research uses a multi-linear regression analysis approach. Data collection is carried out by distributing questionnaires to the head of the accounting sub-sector or the head of the finance and treasurer of revenue and expenditure subdivisions. The findings revealed that the parallel implementation of government accounting principles, apparatus competencies and accounting information systems have a substantial influence on the consistency of financial statements. The government accounting principles application has a major impact on the consistency of the financial statements. Partial competence has a huge influence on the accuracy of the financial statements. Accounting information systems partially have a significant effect on the quality of financial statements.
\end{abstract}

Keywords: Application of Government Accounting Standards, Apparatus Competence, Accounting Information Systems, and Quality of Financial Statements

\section{INTRODUCTION}

The basic aim of the financial statement is to provide information on the financial situation, execution of the budget, cash flow and financial results of the reporting agency that is helpful for consumers in making and reviewing resource allocation decisions. This standard of government accounting is stated in the government regulation No. 71, 2010 [1], which specify that financial statements are structured to record the financial situation and activities carried out by a reporting agency. Then, this matter is confirmed in the government accounting standard statement No. 1 paragraph 9 [2].

Government financial reporting would provide consumers with valuable information on transparency and decision-making, whether they be fiscal, social or democratic. Planning good value accounting results has been a key element for local councils. The quality of financial statements in local authority is the orderly functioning of city government budgets, including administrative order and enforcement. The purpose of this analysis was to examine the impact of government accounting practices, apparatus competencies and accounting information systems on the consistency of local government financial statements.

\section{THEORETICAL VIEW HYPHOTHESIS DEVELOPMENT}

AND

\subsection{Decision-usefulness theory}

The decision-making theory of accounting expertise is defined on the basis of instructions that must be adopted by the components of the financial statements in order to make meaningful for economic decision-making [2].

The principle of decision usefulness provides an idea that the accounting information contained in the financial statements includes elements that need to be considered by the accounting information presenters so that the coverage of the information in the financial statements will satisfy the needs of the decision-makers who can use it. Decision utility principle provides criteria for the 
consistency of accounting knowledge that are valuable in the decisions to be made by consumers.

The principles of the decision-usefulness principle are: 1) The object of accounting is to include financial information on the company for decision-making; 2) the purpose of accounting for investors is to provide financial details on the company that can be used to make investment decisions; 3 ) the lender contains the meaning of the owner and the creditor. This research discusses the enforcement of government accounting principles, the apparatus competence, the accounting information systems and the financial statements consistency [2].

The primary attribute of the knowledge that is valuable in economic decision-making is meaning and reliability. Primary consistency content of use-decision accounting knowledge requires the content of the applicable meaning of its elements, including timeliness, input and predictive value. Reliability material elements are representational fidelity, neutrality and verifiability. In addition, there are also secondary values, as a relation between primary quality, namely comparability and accuracy.

Government accounting principles used by all city councils are intended to make financial reporting equal and consistent to all local governments. The professional machinery shall also promote prompt financial statements. The built-in accounting information framework would also bring importance to the relevance and information visibility provided in local financial statement.

\subsection{The Effect of the Application of Government Accounting Standards on the Quality of Financial Statements in the Regional Apparatus Organization of Palu City}

The adoption of government accounting standard will ensure that the financial reports are compiled in compliance with relevant regulations. Government accounting principles are standards to ensure that financial records are structured to meet the financial information qualifications that are useful to its customers. Useful information is an indication of the compliance of the financial statements with the qualifying information.

Government Accounting Standards are constitutionally enforceable criteria for enhancing the evident of government financial statements [3]. Study on the influence of the adoption of government accounting standards on the quality of financial reporting suggests that the introduction of the accounting standards of government has a substantial impact on the government financial reporting of quality [4]. Based on the description, the hypothesis of this research is formulated as follows:

H1: The application of government accounting standards has a significant effect on the quality of local government financial reports

\subsection{The Effect of Apparatus Competence on the Quality of Financial Reports in the Regional Apparatus Organization of Palu City}

Human capital decides whether or not an entity succeeds, in addition to the provision of services and equipment. The performance of human capital is required to contribute optimally to the accomplishment of corporate objectives. Competence is one of the qualities of quality human capital. The willingness to do a task that is based on expertise and experience and is accompanied by the work attitudes and attitudes demanded by the position [5]. Financial management of government departments can be well handled if the apparatus or staff in it are qualified, have an educational history, are also educated and trained and have financial expertise.

Research on the effects of apparatus competence on the local government financial reports quality in Palu City notes that the competence of the apparatus has a substantial influence on the government financial reports quality [6]. Based on this description, the research hypothesis is formulated as follows:

$\mathrm{H} 2$ : Apparatus competence has a significant effect on the quality of local government financial reports

\subsection{The Influence of Accounting Information Systems on the Quality of Financial Statements in Regional Apparatus Organizations in Palu City}

The accounting information system is structured to provide the relevant data for decision-making by management. Accounting information system is a media that can help to gathers, tracks, stores and manages information for decision-making. Business documentation is handled by an accounting information system that explains different economic activities or what is widely referred to as transactions within an entity. The effects of data analysis are information needed both by the company itself and outside the organization, with the exception of rivals in the business world [7].

Analysis on the influence of accounting information systems on the financial statements quality has demonstrated that the accounting information system has a significant impact on the financial statements quality [8]. Therefore, the hypothesis of this research is formulated as follows:

H3: The accounting information system has a significant effect on the quality of local government financial reports

\section{RESEARCH METHOD}

The data was obtained through delivered the questionnaires directly to 62 respondents with a purpose to achieve a high degree of response. The Respondents consisted of the head of accounting subdivision, 25 head of finance, 7 treasurers of revenue and 29 treasurers of spending. Multiple regression SPSS was applied to analyse the data. 


\section{RESULTS}

\subsection{Validity and Reliability}

The results of the convergent validity test show that the loading value for each indicators item are more than 0.50 which mean that they meet the criteria. The results also showed that the reliability value for each variable had a value morethan 0.70 . Thus, it can be said that all the variables in this study meet the criteria.

\subsection{Multiple Linear Regression Analysis}

The data processing results with the help of SPSS 21 are shown in table 1. Based on the coefficient values which recourse obtained from analysis of multiple linear regression that shown in table 1 then the insert into the multiple regression model with the following formulation:

$$
\mathrm{Y}=1,246+0,134 \mathrm{X} 1+0,250 \mathrm{X} 2+0,469 X 3+\mathrm{e}
$$

Based on the research findings of statistical analysis, government accounting standard factors have a huge influence on the visibility of the financial report of local government. This suggests that, as the implementation of government accounting practices progresses, the consistency of local government financial reporting high degree of experience in the apparatus. The higher the competence of the staff, the better the level of the financial statements. Accounting knowledge is expressed in the type of laws that must be complied with by the elements of financial statements in order to be useful for financial decision [1].

The findings of the third hypothesis test suggest that the factors of the accounting information system have a significant impact on the consistency of the financial records consistency of the Palu government. These findings suggest that the accounting information system would strengthening the financial statements consistency. The accounting information system has a strong contribution to the financial reports quality, especially in the process of preparing and presenting the result of financial reports. [7].

\section{CONCLUSION}

The research concludes that the consistency of local authority financial reporting is influenced by the implementation of government accounting practices, apparatus expertise and accounting information systems. In the Government Accounting Principles, financial reporting must be based on these standards in order to provide complete facts and to provide accountable,

Table 1. Results of Multiple Linear Regression Analysis

\begin{tabular}{|l|c|c|c|}
\hline Independent Variables & Regression Coeficient & t- test & Sig. \\
\hline X1 & 0.134 & 2.363 & 0.022 \\
\hline X2 & 0.250 & 2.357 & 0.022 \\
\hline X3 & 0.469 & 2.726 & 0.008 \\
\hline Constanta $=1,246$ & \multicolumn{2}{|c|}{ Adjusted R Square $=0,452$} & Sig. $F=0,000$ \\
\hline Multiple-R $=0,692$ & \multicolumn{2}{|c|}{} \\
\hline
\end{tabular}

produced is also improving. The local government financial reports quality produced is getting better. The financial reports require the government accounting standards in order to present complete information and produce accountable, reliable and trustworthy financial reports.

Government accounting standards are needed in order to prepare financial reports which include budget realization reports, operational reports, cash flow reports, changes in equity reports and notes to financial statements. The government accounting standards committee states that principles are applied in the planning and filing of government financial accounts. Therefore, the financial statements must be based on these principles in order to provide complete and credible reports on the financial statements that are published.

The outcome of the test of the second hypothesis showed that the variable of competence of the apparatus has a major impact on the consistency of the financial statements of the Palu government. These results show that increasing the knowledge of the apparatus would also enhance the efficiency of the financial statements. As a result, it can be concluded that the majority have a credible and reliable financial reports. The enhanced ability of the apparatus would also further enhance the productivity of local authority financial results. In addition, the accounting information system has significantly contributed to the financial statements accuracy, especially in the planning and presentation of the result of financial report.

\section{AUTHORS' CONTRIBUTIONS}

All authors contribute in this research and no potential conflicts.

\section{ACKNOWLEDGMENTS}

This publication was funded by Accounting Department of Tadulako University.

\section{REFERENCES}

[1] "Peraturan Pemerintah No. 71 tentang Standar Akuntansi Pemerintahan," Republik Indonesia, Jakarta, 2010. 
[2] Mahmudi, "Laporan Keuangan Sektor Publik, antara Konsep dan Praktek," Jurnal Akuntansi dan Keuangan Sektor Publik, vol. Vol. 3 nomor 1, 2003.

[3] B. Indra, Akuntansi Sektor Publik, Jakarta: Erlangga, 2006.

[4] D. K. Adhi dan Y. Suhardjo, "Pengaruh Penerapan Standar Akuntansi Pemerintahan dan Kualitas Aparatur Pemerintahan Daerah Terhadap Kualitas Laporan Keuangan (Studi Kasus Pada Pemerintah Kota Tual)," Jurnal STIE Semarang, vol. Vol 5, 2013.

[5] Wibowo, Manajemen Kinerja, Jakarta: PT Raja Grafindo Persada, 2008.

[6] R. Ngguna, Muliati dan F. M. Saleh, "Pengaruh Kompetensi Aparatur, Pemanfaatan Sistem Informasi Keuangan dan Peran Internal Audit Terhadap Kualitas Laporan Keuangan Pemerintah Daerah Kota Palu," E Jurnal Katalogis, vol. Vol 5, pp. 34-42, 2017.

[7] M. B. Romney dan S. P.L, Sistem Informasi Akuntansi, Edisi Kesembilan penyunt., Jakarta: Salemba Empat, 2006.

[8] R. Juwita, "Pengaruh Implementasi Standar Akuntansi Pemerintahan dan Sistem Informasi Akuntansi Terhadap Kualitas Laporan Keuangan," Jurnal Trikonomika, vol. Vol 12, pp. 201-214, 2013. 